\title{
Potash mining effluents and ion imbalances cause transient stress in adult common roach, Rutilus rutilus
}

Nora Baberschke, Laura Schulzik, Torsten Preuer, Klaus Knopf (ib https://orcid.org/0000-0001-9401-8145, Thomas Meinelt, Werner Kloas

DOI

https://doi.org/10.1016/j.ecoenv.2019.05.069

Original publication date

29 May 2019 (Available online)

Document version

Accepted manuscript

Published in

Ecotoxicology and Environmental Safety

\section{Citation}

Baberschke N, Schulzik L, Preuer T, Knopf K, Meinelt T, Kloas W. Potash mining effluents and ion imbalances cause transient stress in adult common roach, Rutilus rutilus. Ecotoxicology and Environmental Safety. 2019;180:733-41 


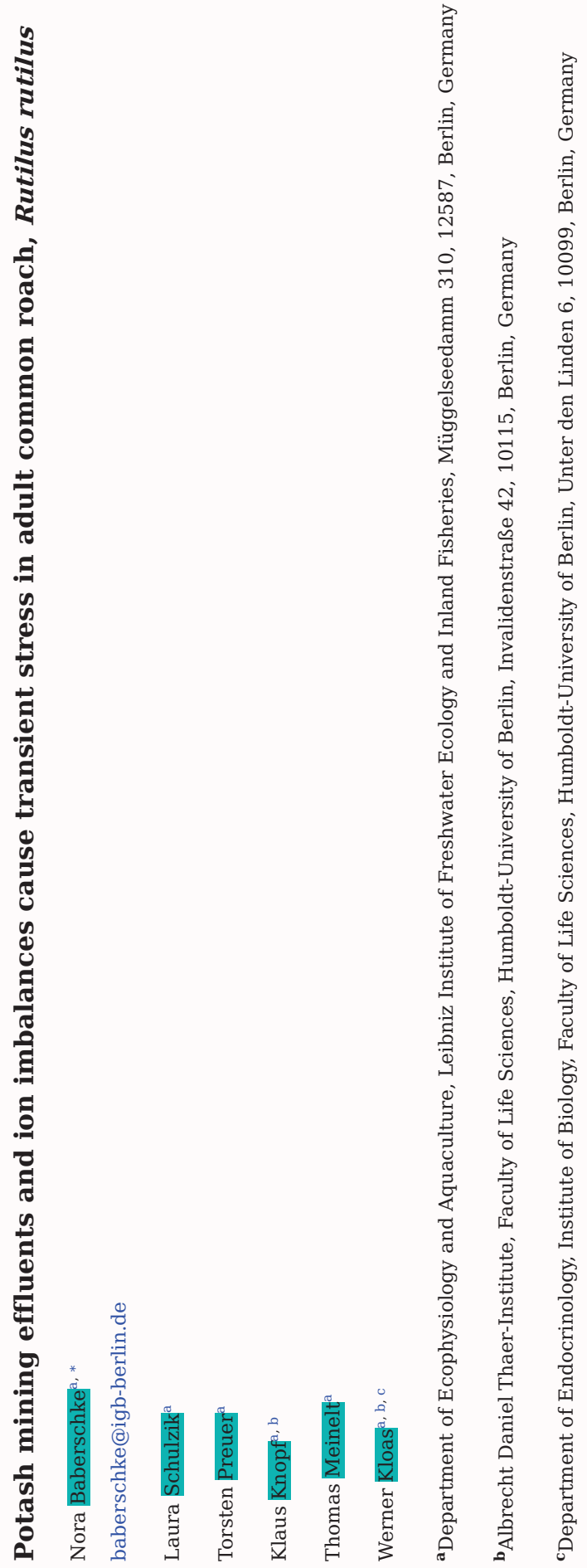

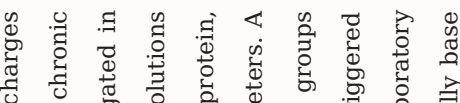
चี

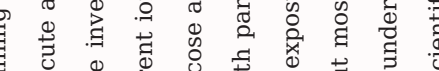

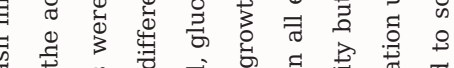

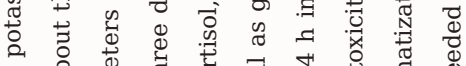

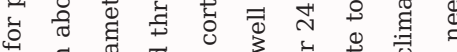

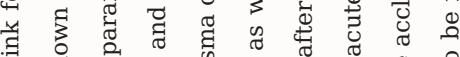

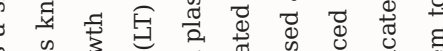
(5 ) 表

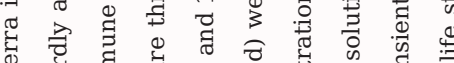

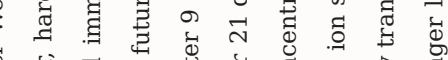

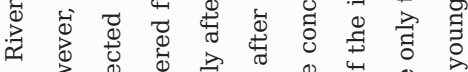

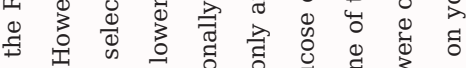

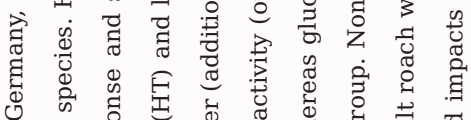
ब

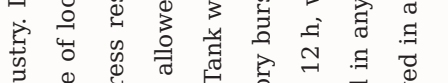

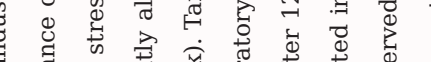
๑

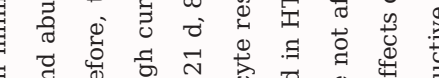

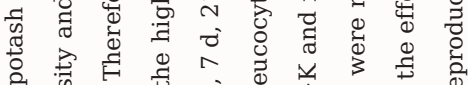

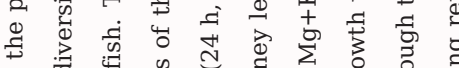

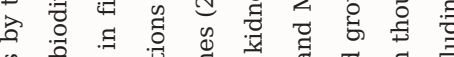

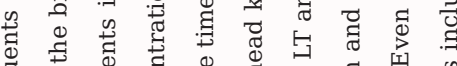
釆

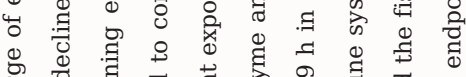
总

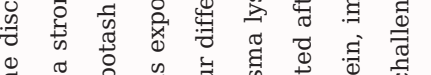

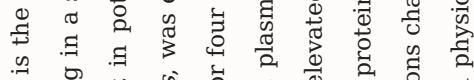
क

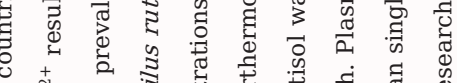

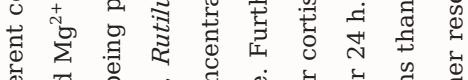

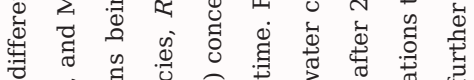

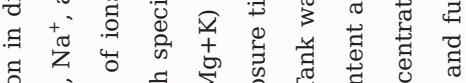

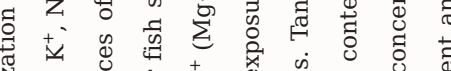

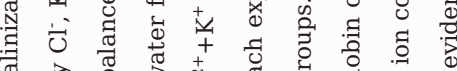

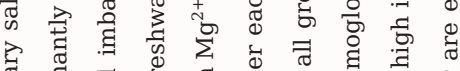

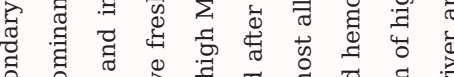

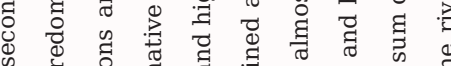
焉 击

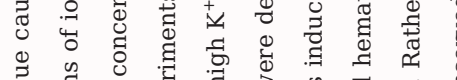

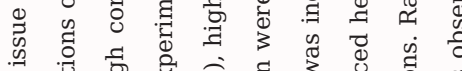

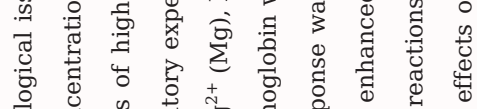
跣

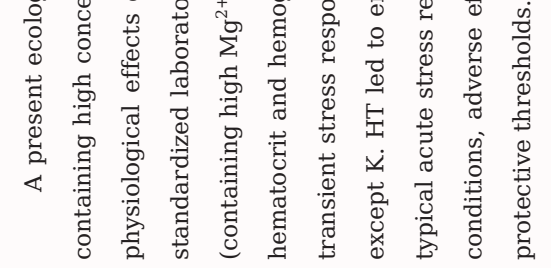




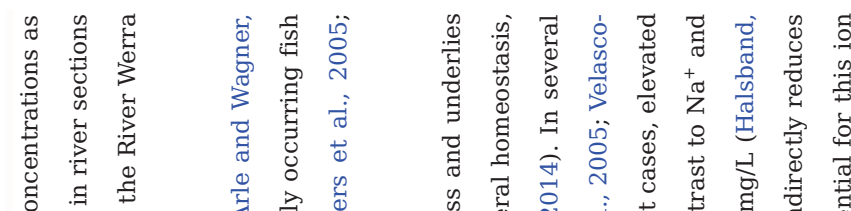

苟苛

译

ᄅ :

है 00 ป

..

융 范

㝴

总

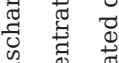

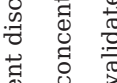

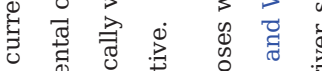

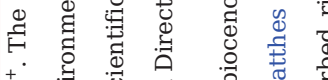

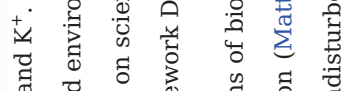

శี

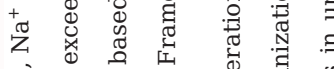

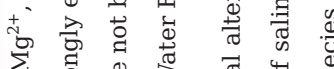

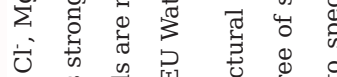

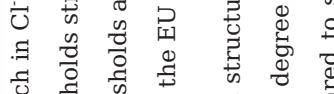

㺃

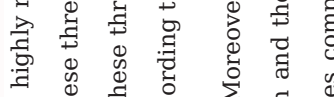

苟

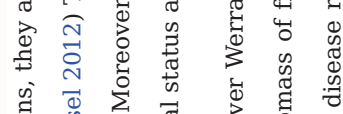

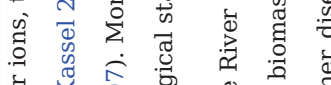

范范

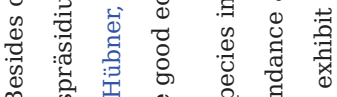

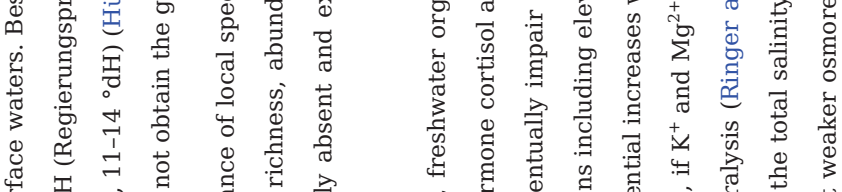

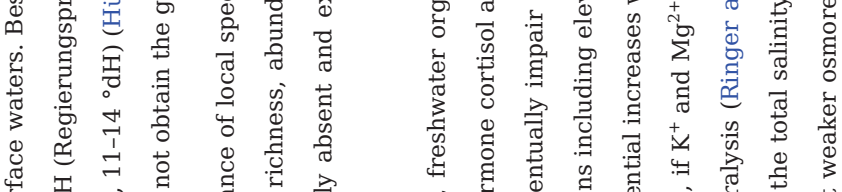

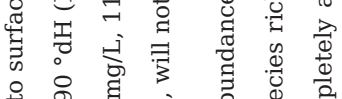

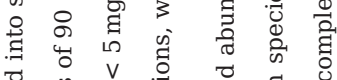

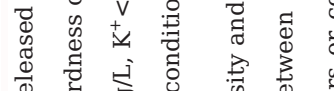

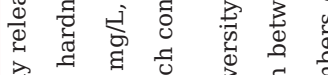

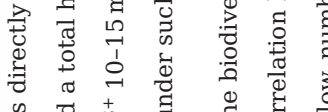

๑

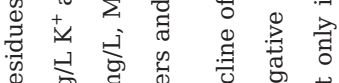

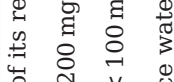

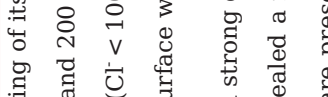

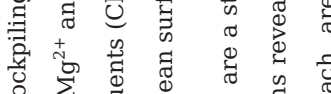

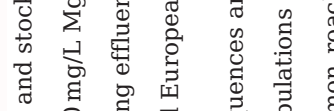

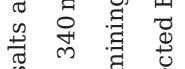

क 1 है

范范

范

焉

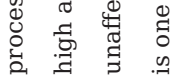

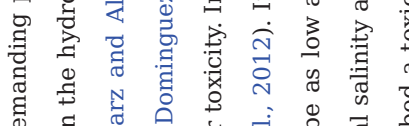

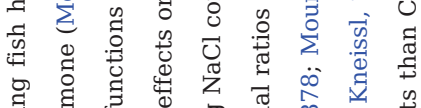

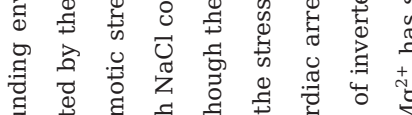

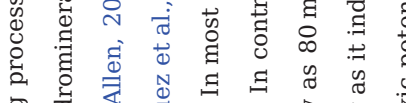

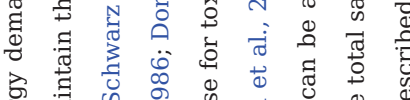

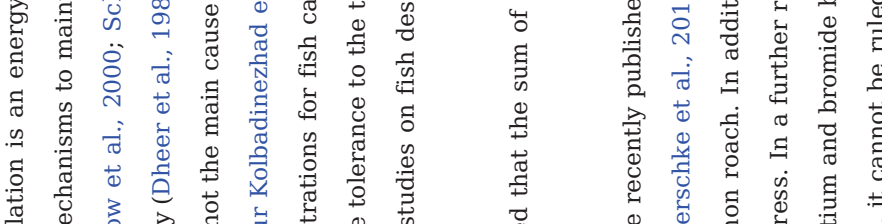

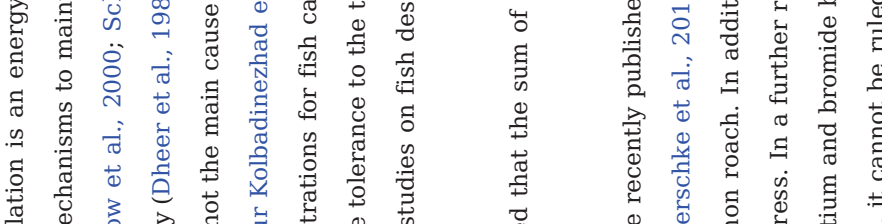

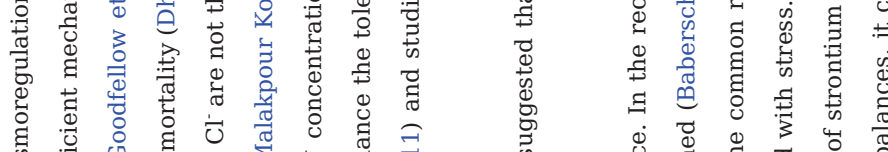

它

峲泀

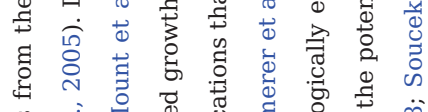

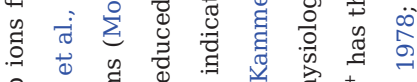

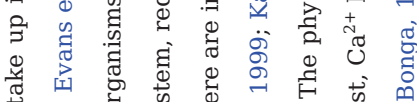

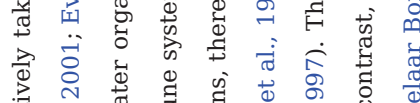

蒈

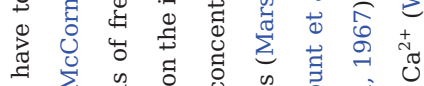

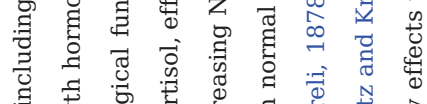

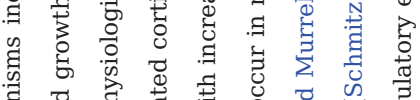

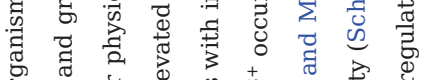

完

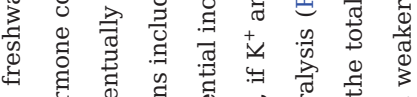

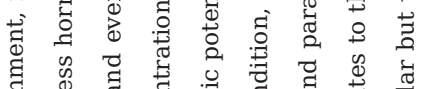

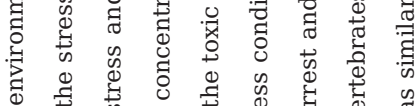

疍

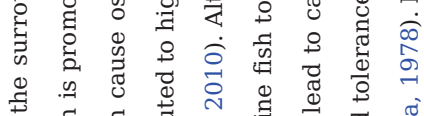

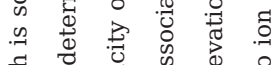

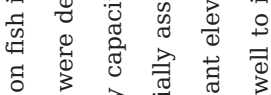

品

荧壳

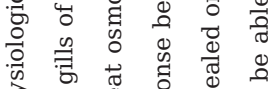

总

节

चี

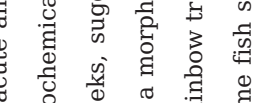

3 बै

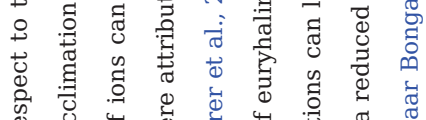

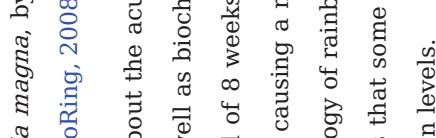

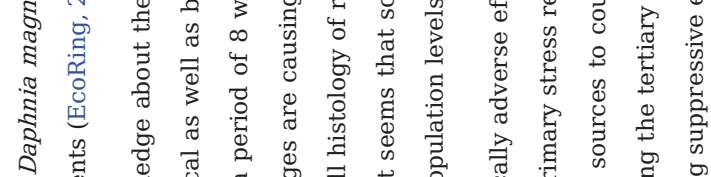

离 章

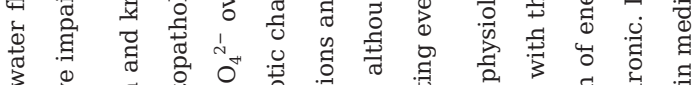

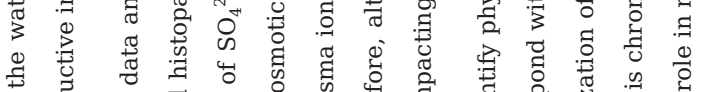

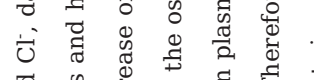

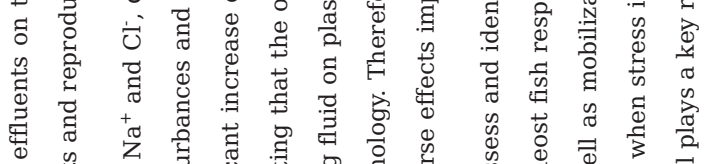

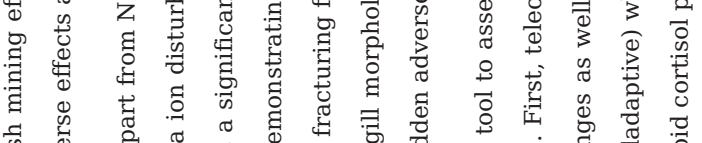

范

峸

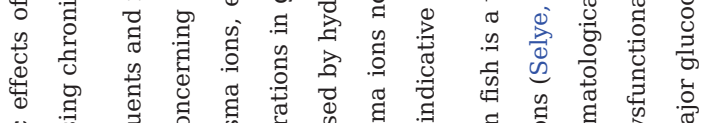

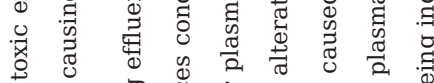

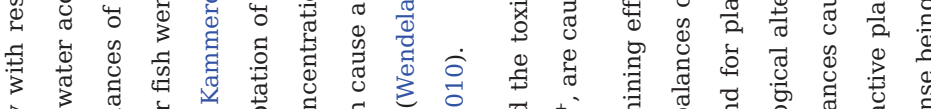

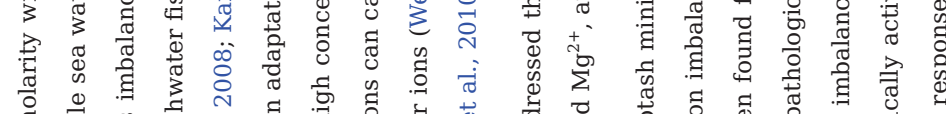

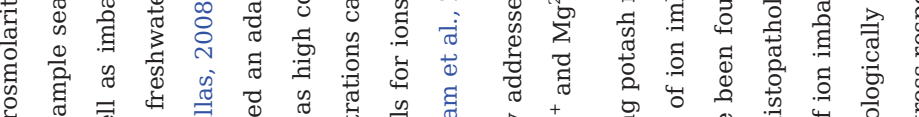
范

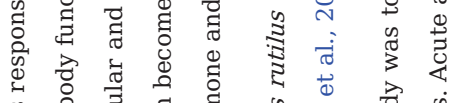

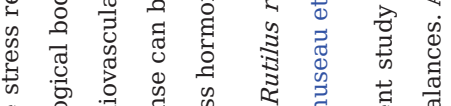

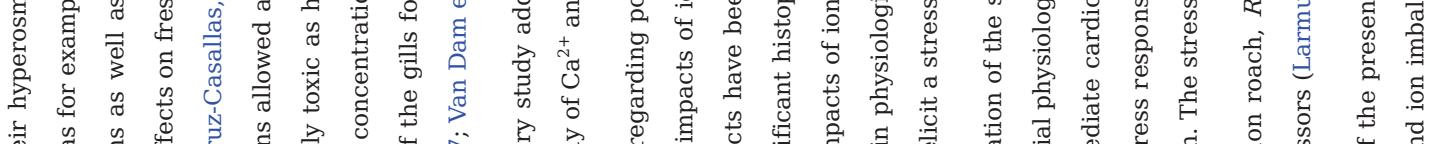

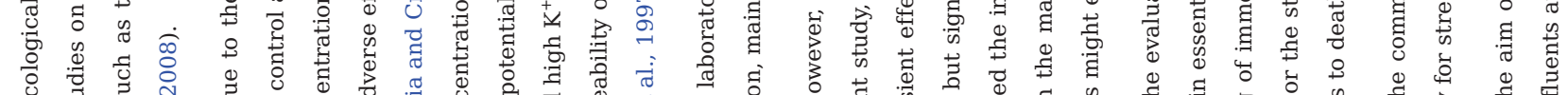

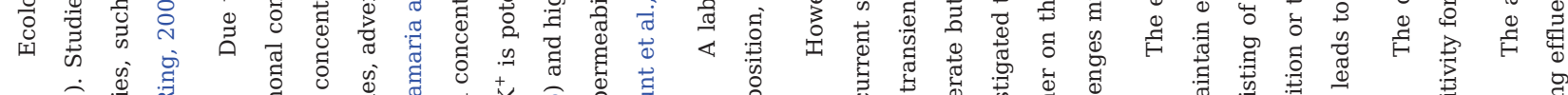

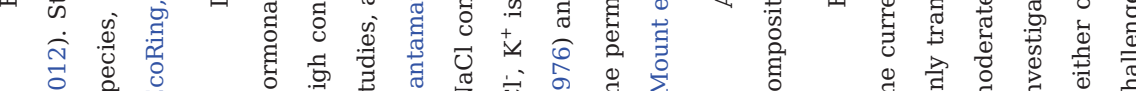

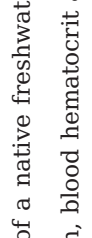
节䒿 శี 营 ह $\begin{array}{ll}0 & 0 \\ 0 & 0 \\ 0 & 0 \\ 0 & 0 \\ 0 & 0\end{array}$

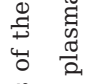

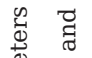
范 Ð च ¿

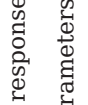
$\begin{array}{ll}0 & 0 \\ 0 & 0 \\ 0 & 0 \\ 0 & 0\end{array}$ 进

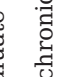
ฮี

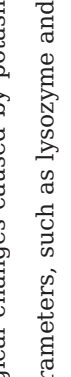

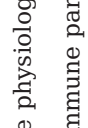

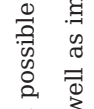
$\begin{array}{ll}2 & 0 \\ 0 & 3 \\ 0 & 0 \\ 0 & 0 \\ 0 & 0\end{array}$ 흥 के 政 


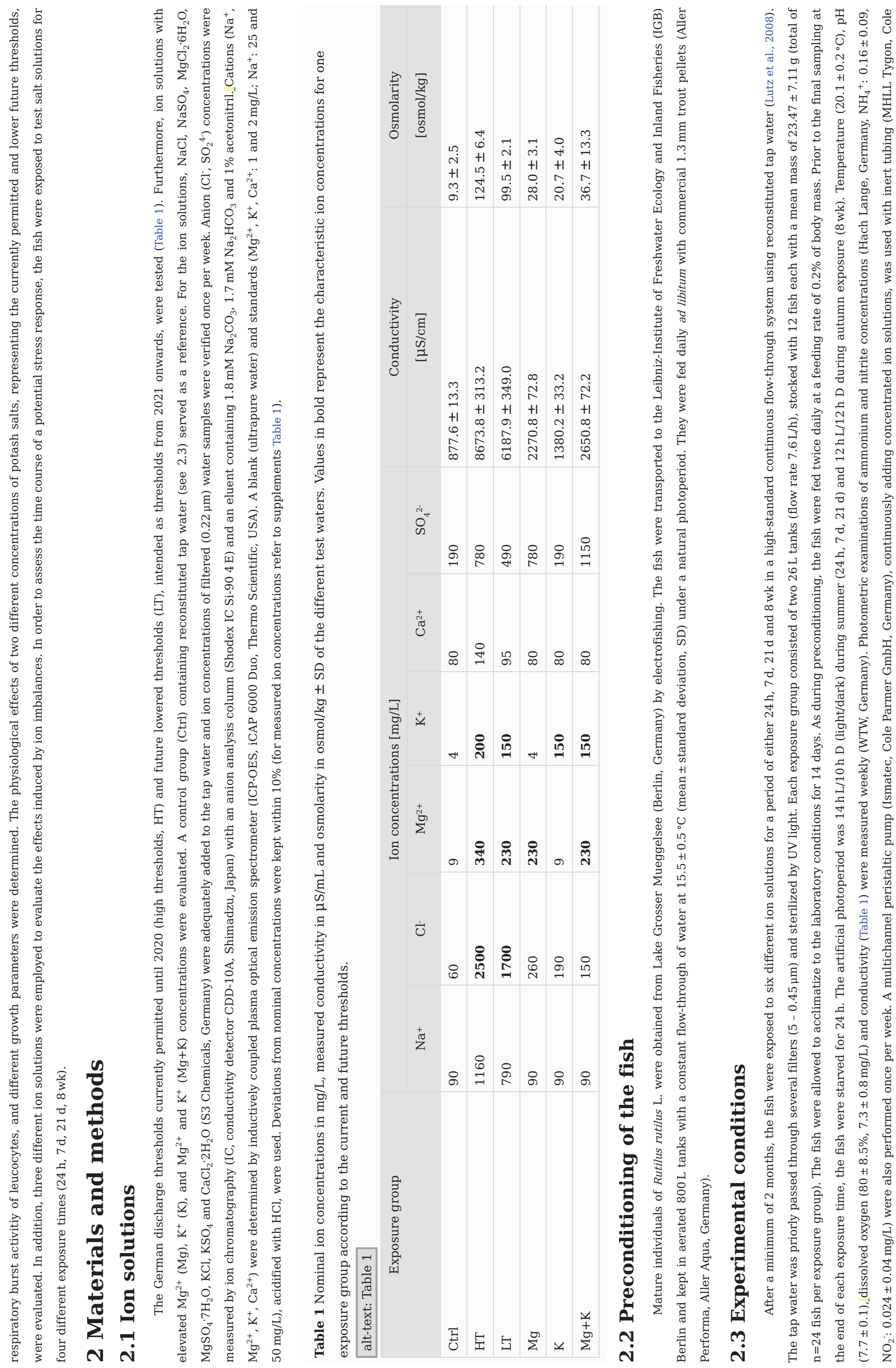




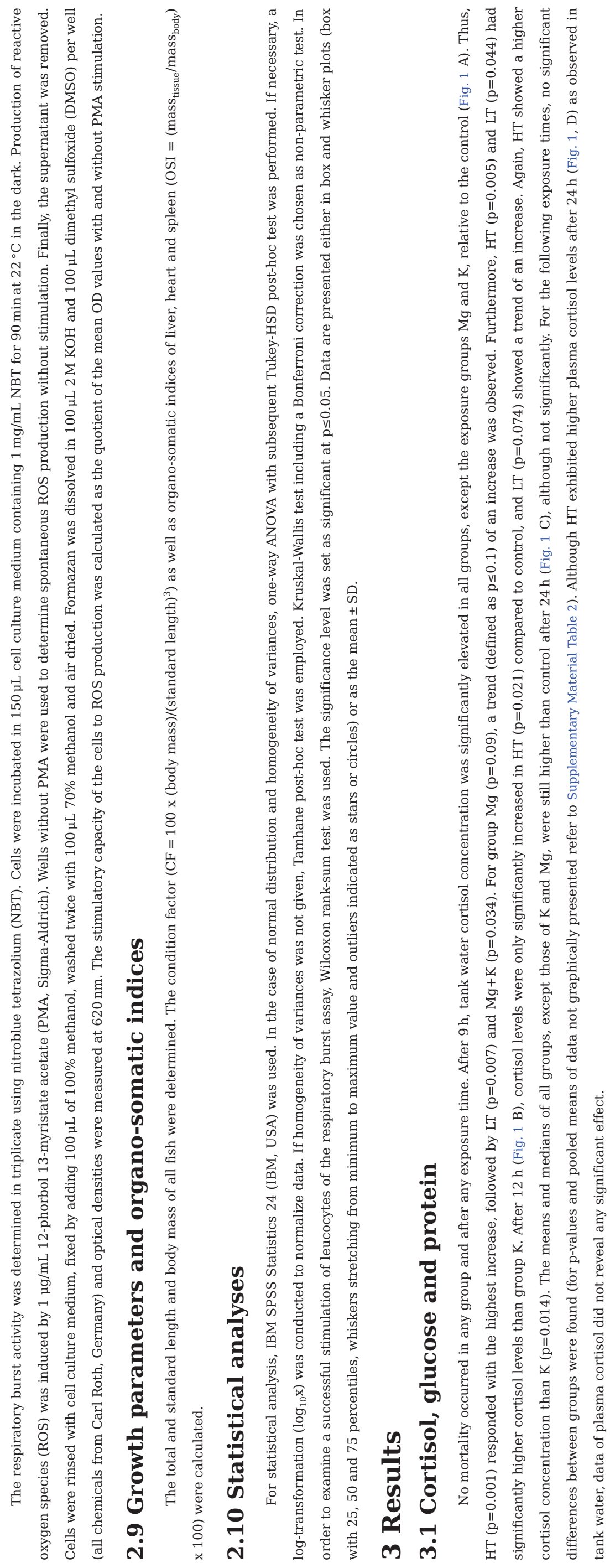



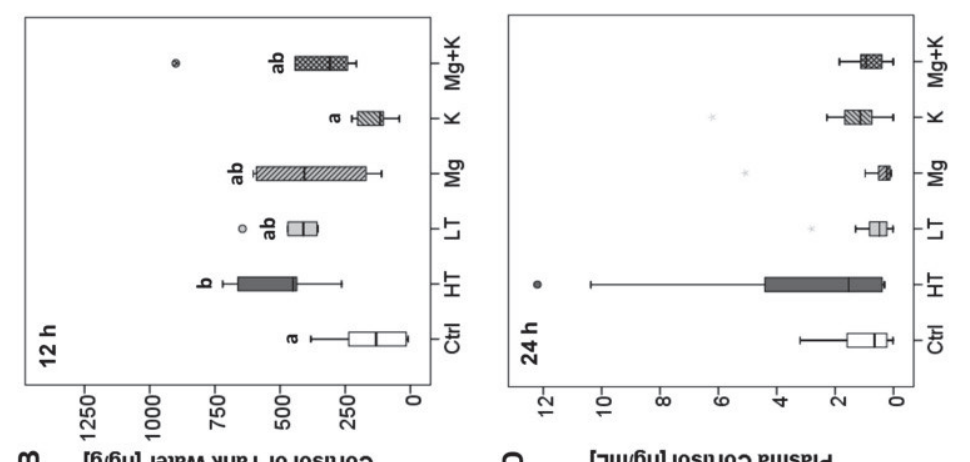

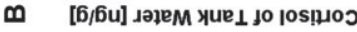

ด [ךu/6u] |Os!น०ว euse/d
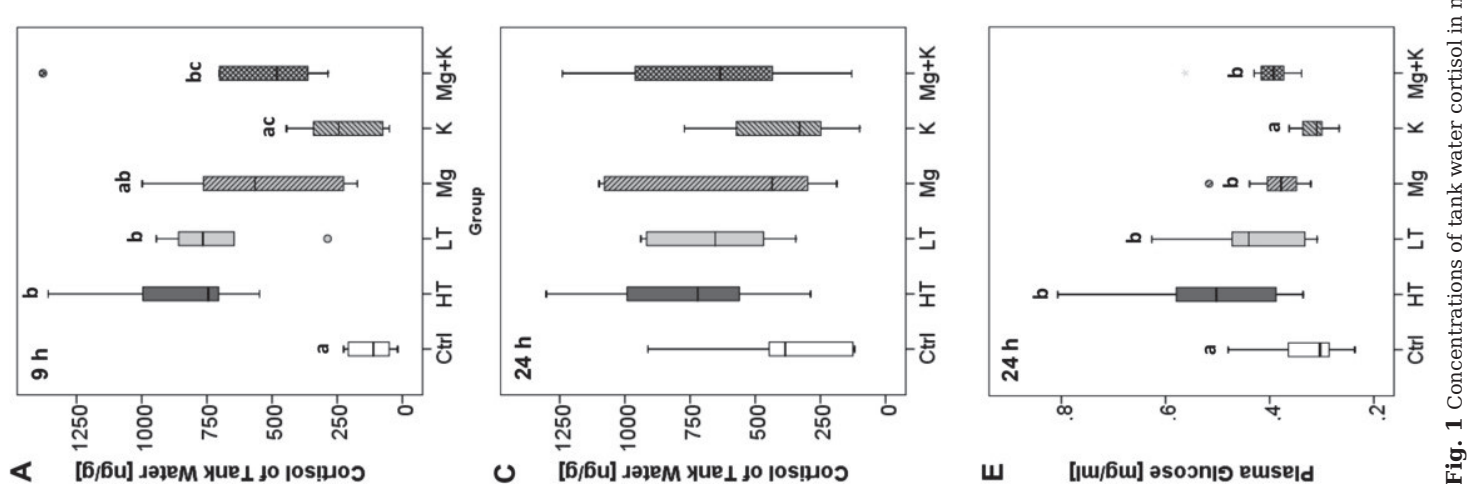

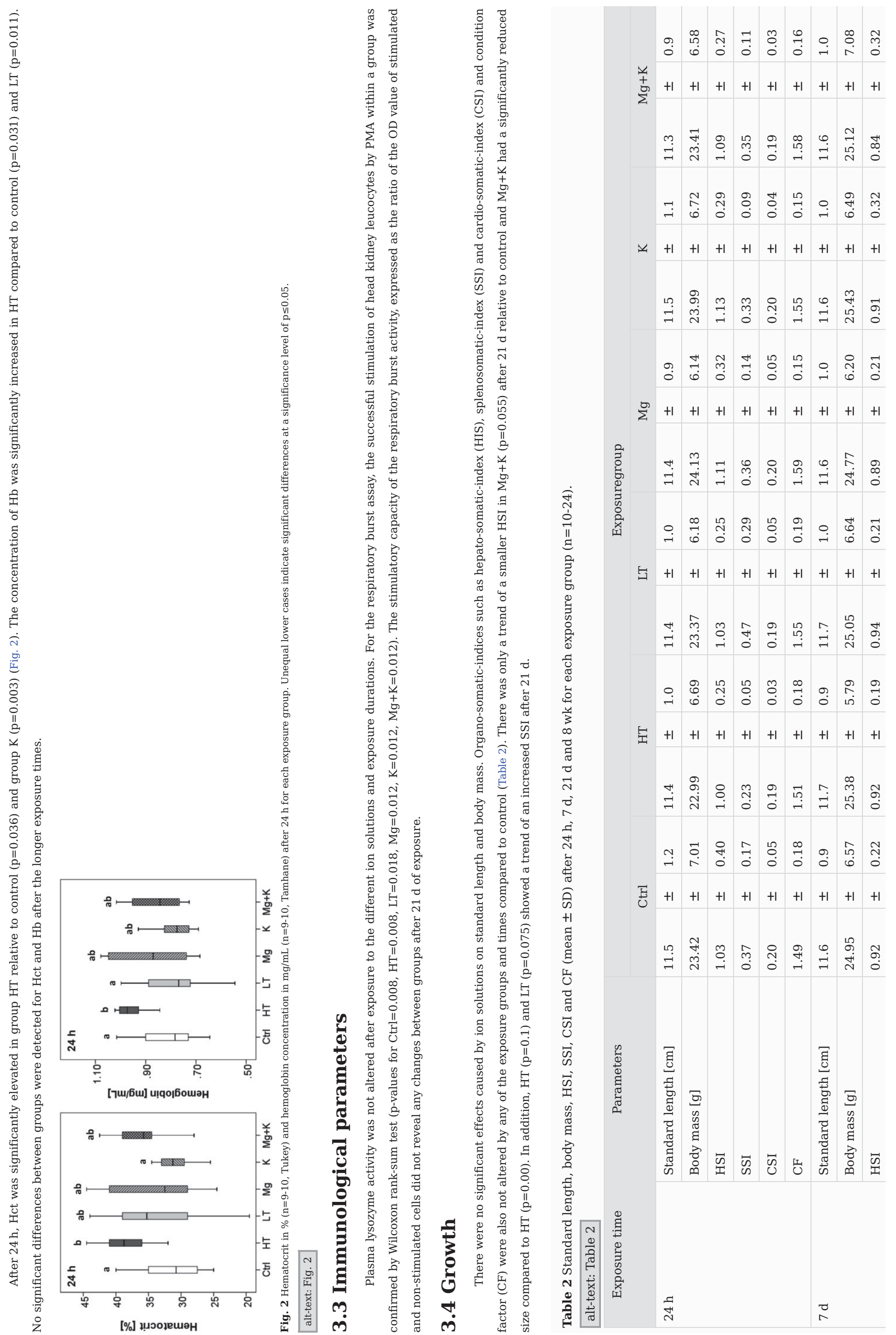


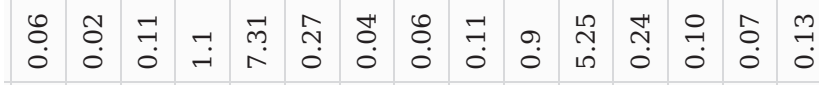
$\begin{array}{llllllllllllllllllllll}n & +1 & +1 & +1 & +1 & +1 & +1 & +1 & +1 & +1 & +1 & +1 & +1 & +1 & +1\end{array}$

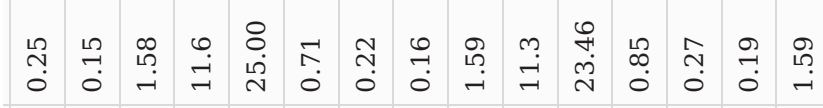

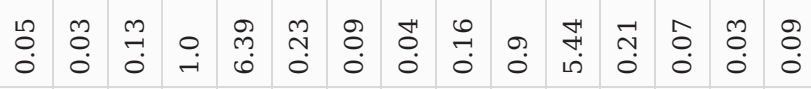

$\begin{array}{lllllllllllllllllllll}n & +1 & +1 & +1 & +1 & +1 & +1 & +1 & +1 & +1 & +1 & +1 & +1 & +1 & +1\end{array}$

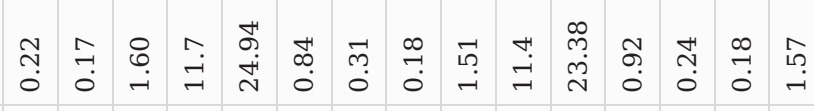

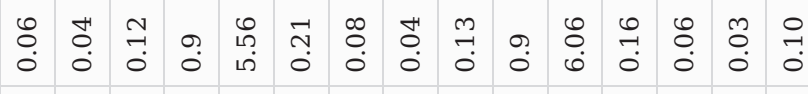

$\begin{array}{llllllllllllllllllll}+1 & +1 & +1 & +1 & +1 & +1 & +1 & +1 & +1 & +1 & +1 & +1 & +1 & +1 & +1\end{array}$

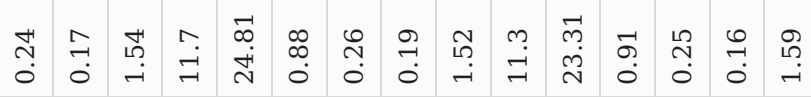

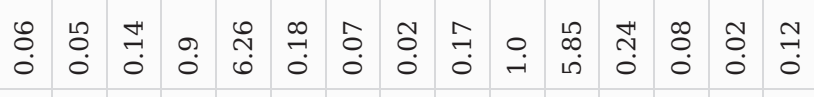

$\begin{array}{lllllllllllllllllllllll}+1 & +1 & +1 & +1 & +1 & +1 & +1 & +1 & +1 & +1 & +1 & +1 & +1 & +1 & +1\end{array}$

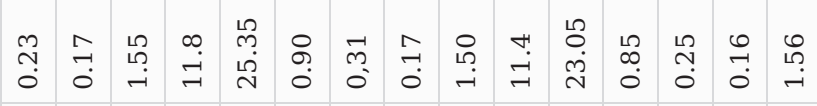

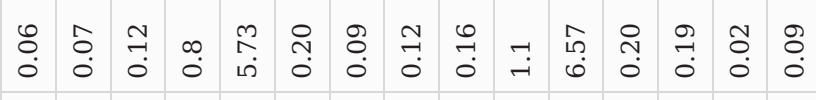

$\begin{array}{lllllllllllllllllllllllll}n & +1 & +1 & +1 & +1 & +1 & +1 & +1 & +1 & +1 & +1 & +1 & +1 & +1 & +1\end{array}$

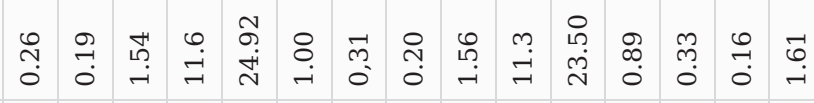

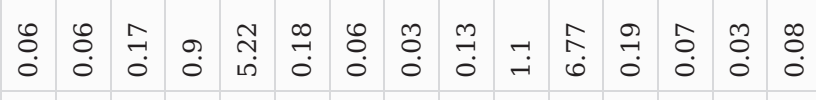

$\begin{array}{llllllllllllllllllll}n & +1 & +1 & +1 & +1 & +1 & +1 & +1 & +1 & +1 & +1 & +1 & +1 & +1 & +1\end{array}$

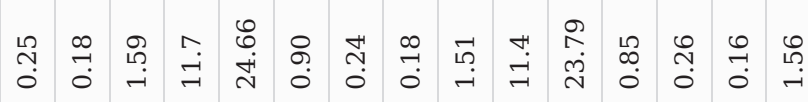

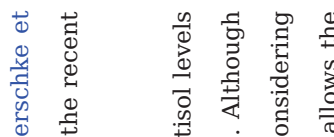

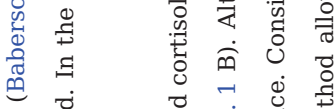

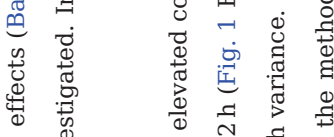

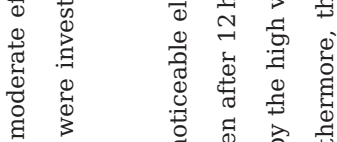

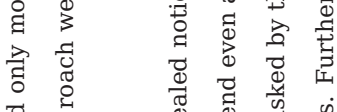

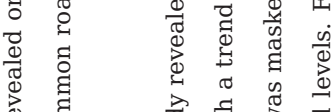

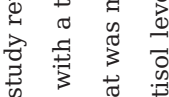

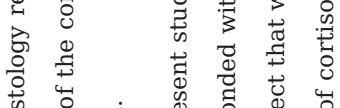

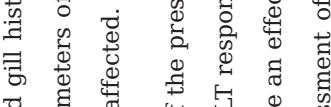

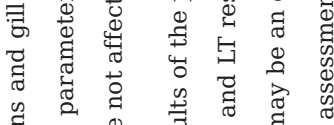

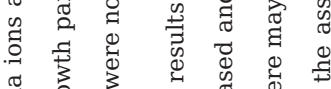

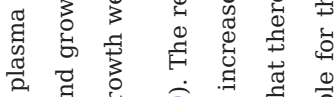

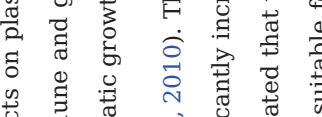

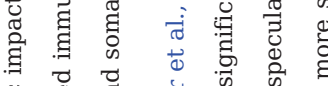

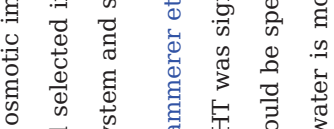

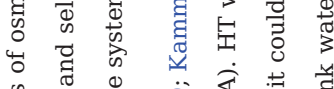

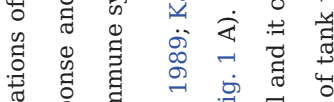

我要

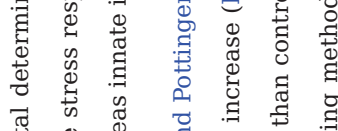

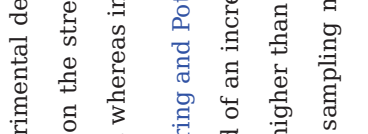

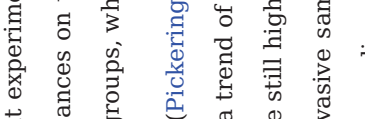

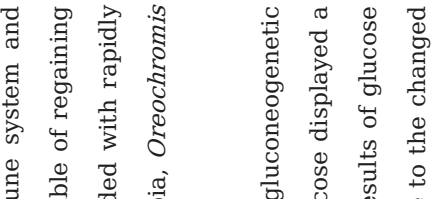

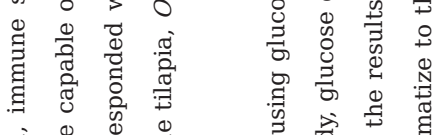

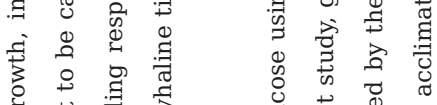

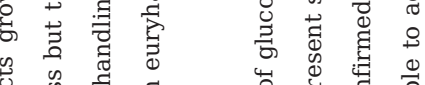

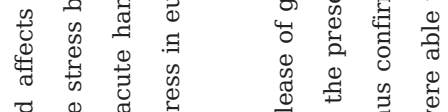

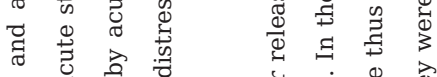

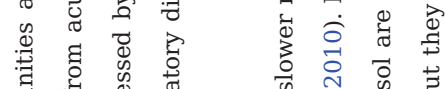

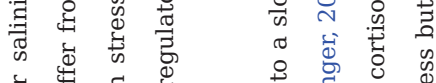

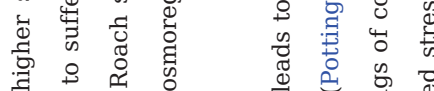

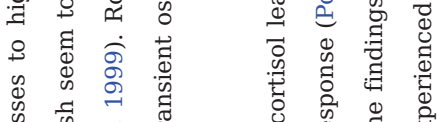

善茄

$\begin{array}{lll} & \\ 0 & 0 & 0 \\ 0\end{array}$

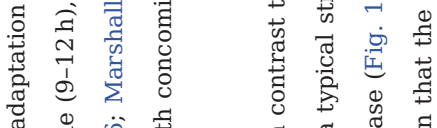

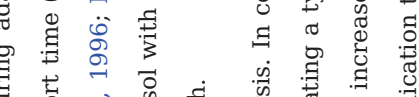

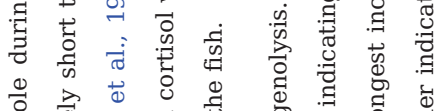

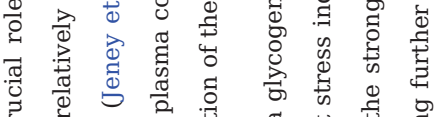
(5)

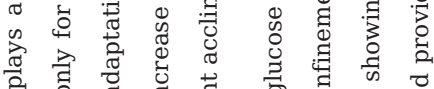

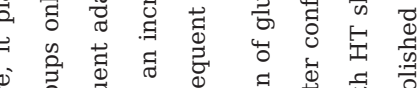

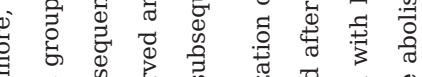

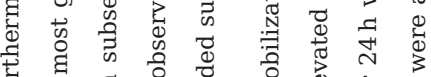

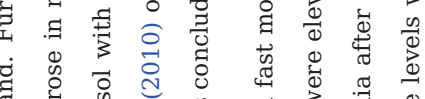

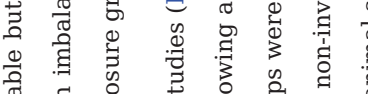

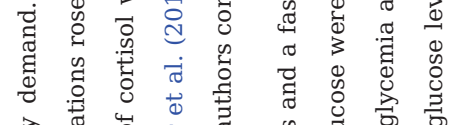

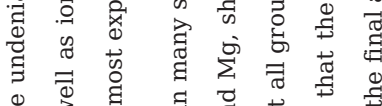

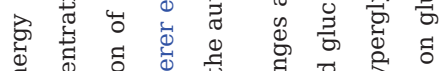

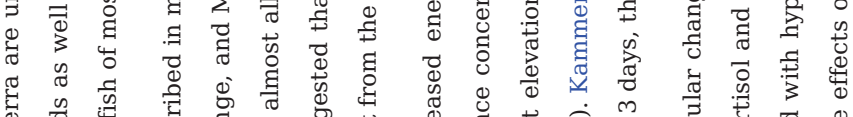

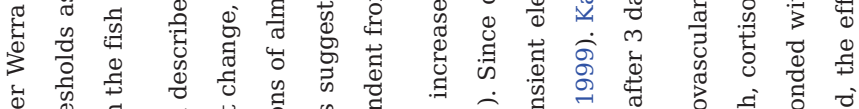

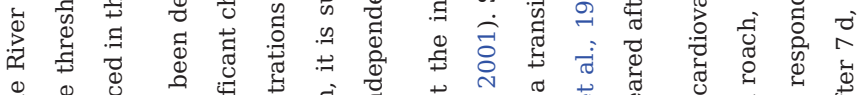

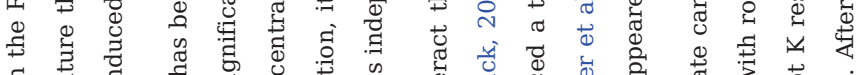

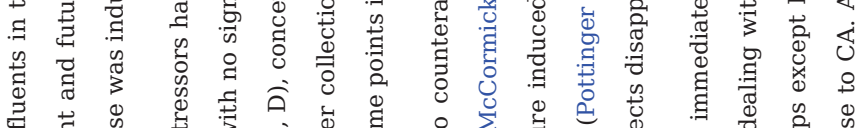

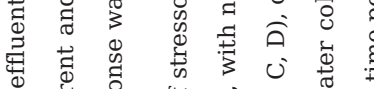

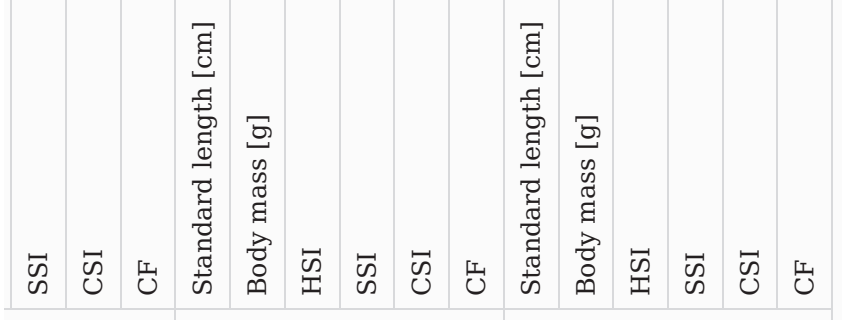

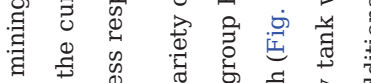

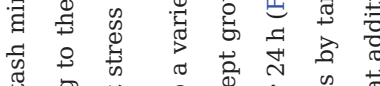

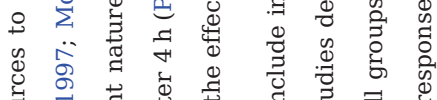

0
4

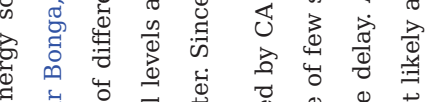

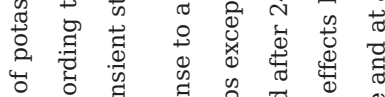

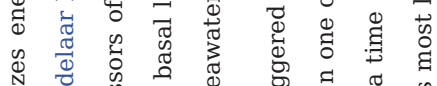

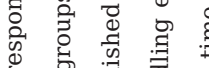

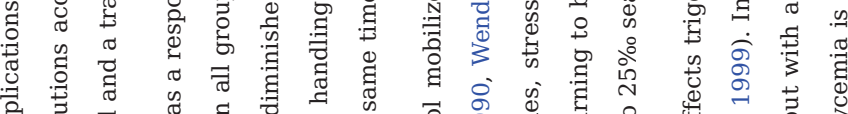

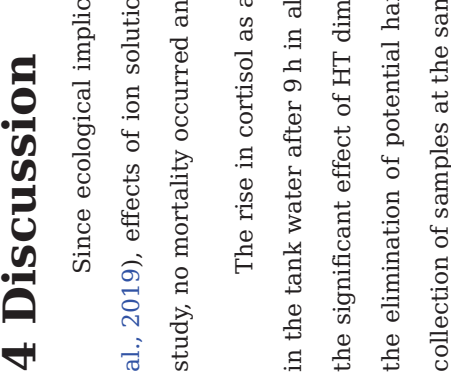

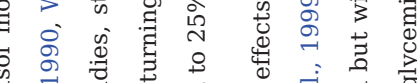

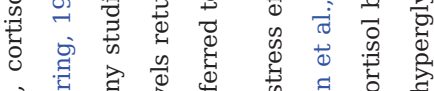

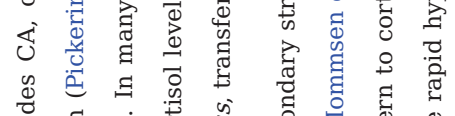

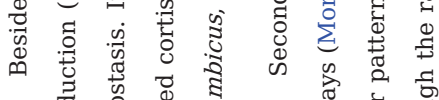




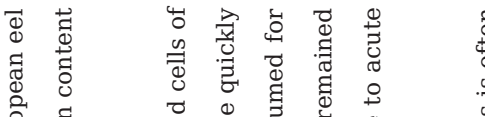

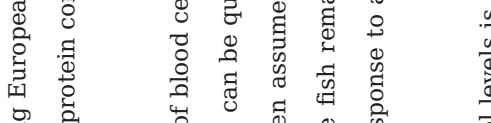

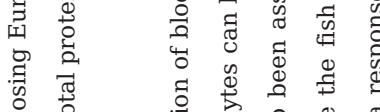

:

屯

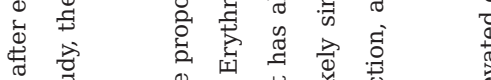

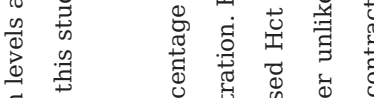

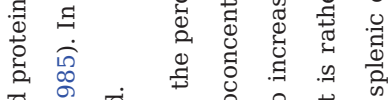

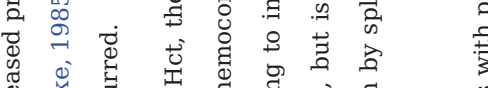

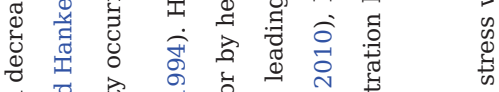

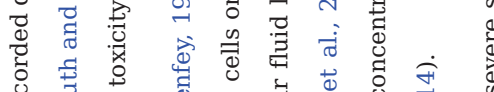

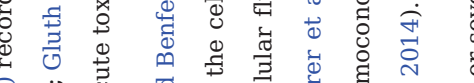

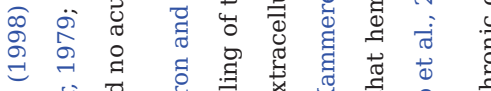

ब

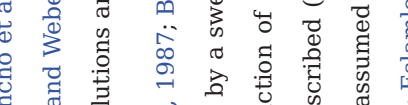

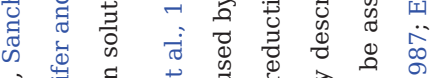

ब密

वี 若

๖

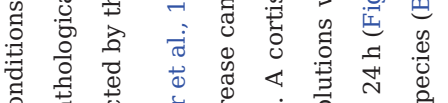

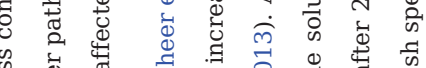

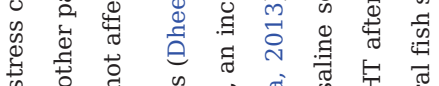

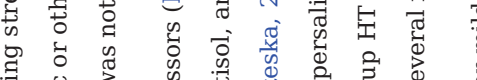

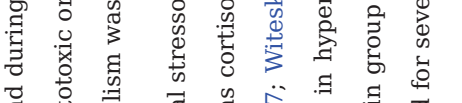

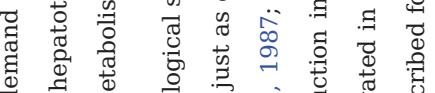

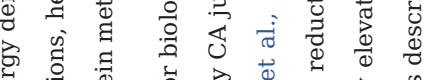

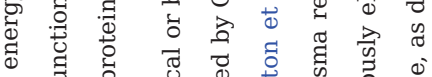

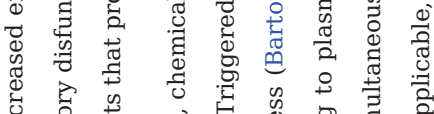

戛

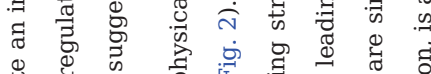

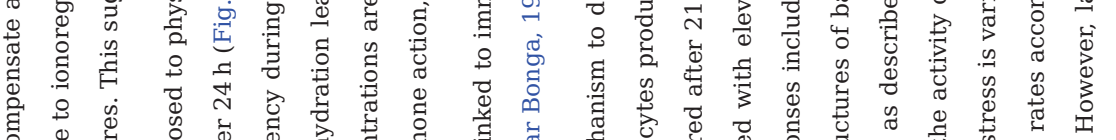

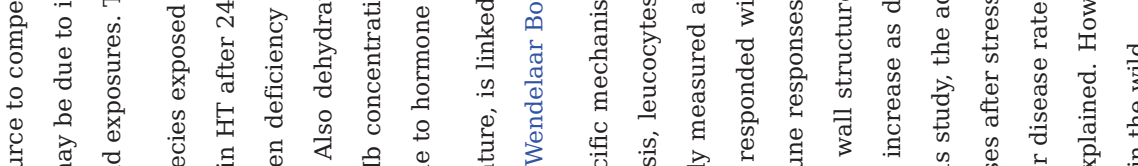

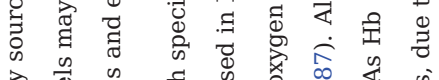

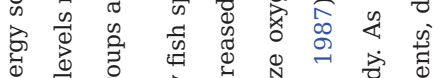

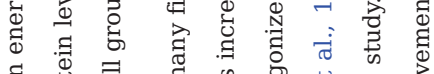

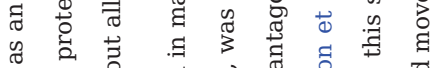

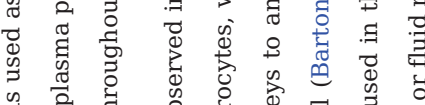

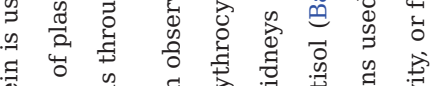

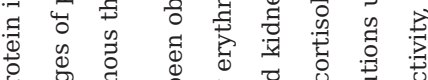

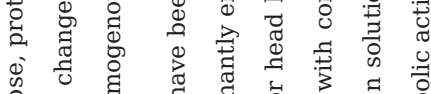

范

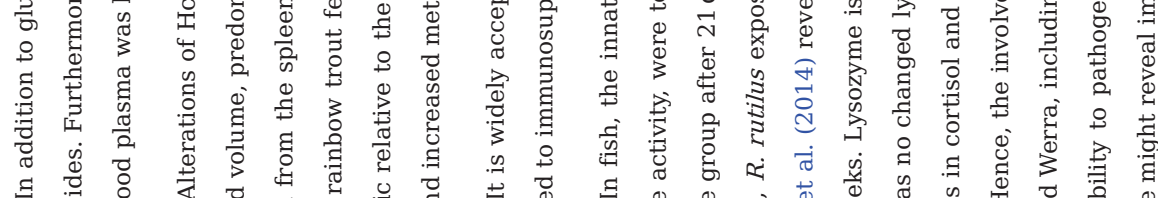

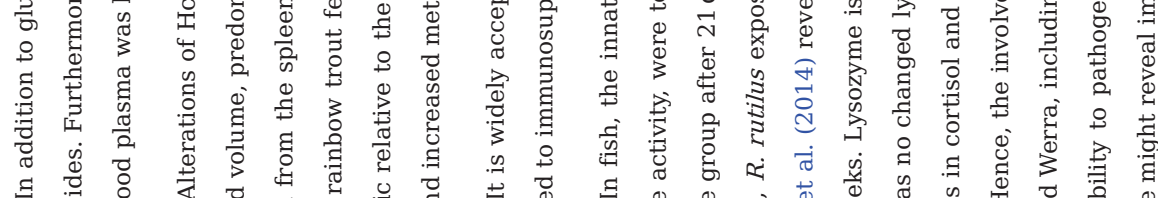

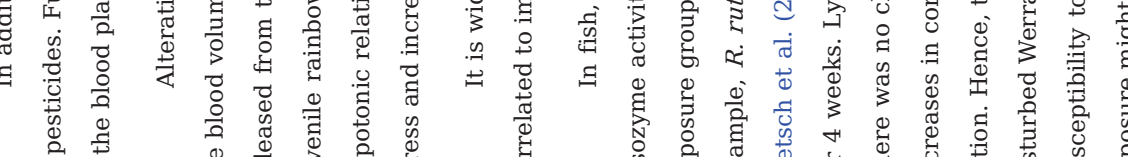

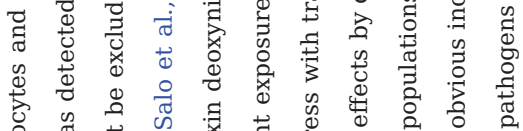

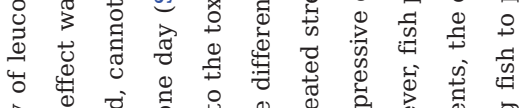

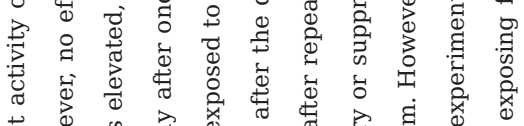

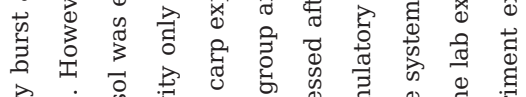

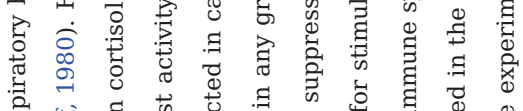

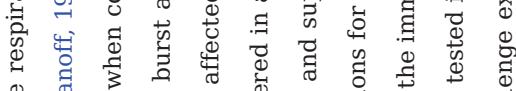

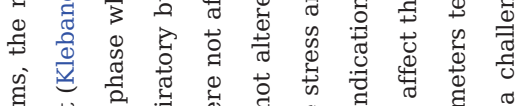

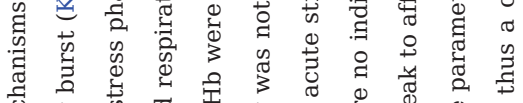

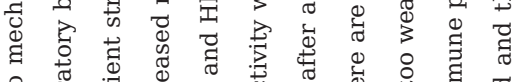

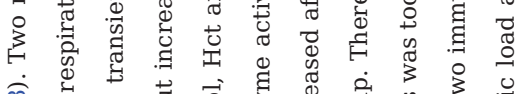

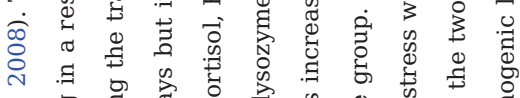

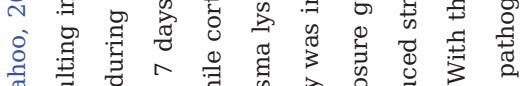

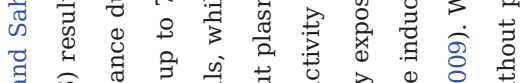

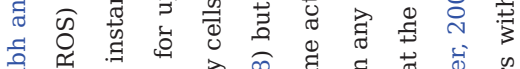

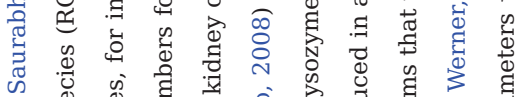

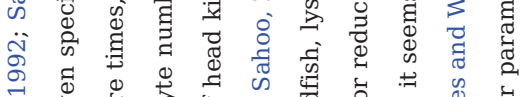

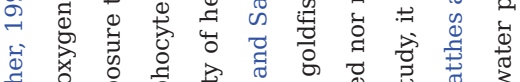

要

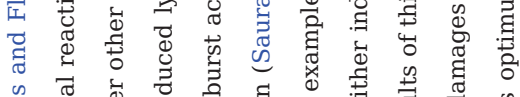

ڤ

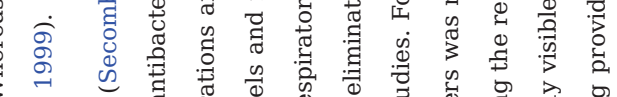

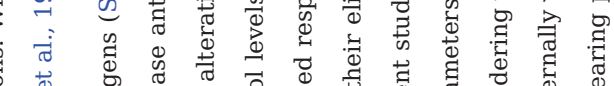

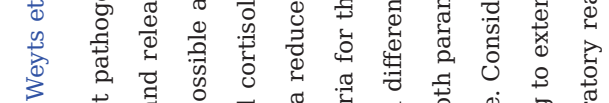

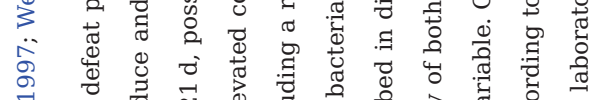

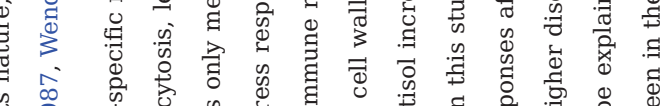

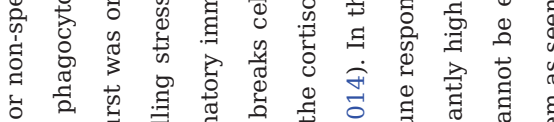

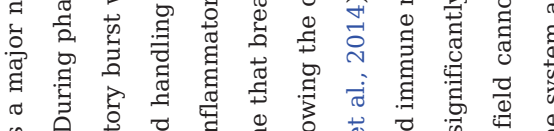

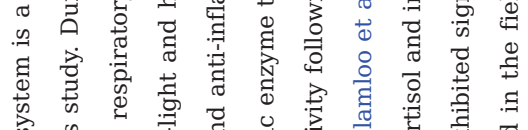
क

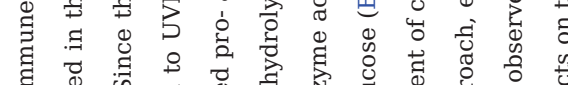
घี

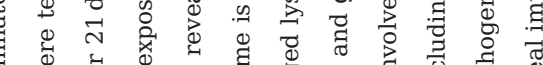

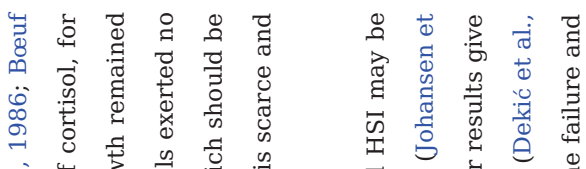

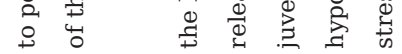

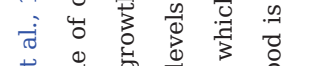

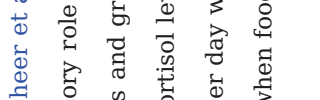

㐘

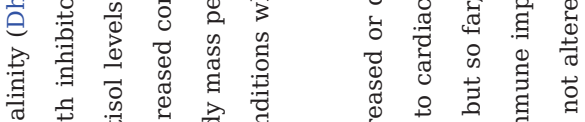

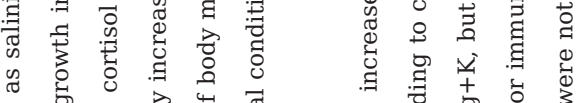

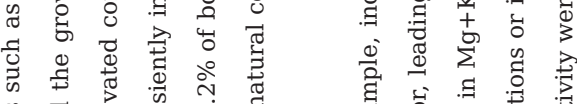

总

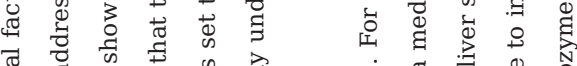

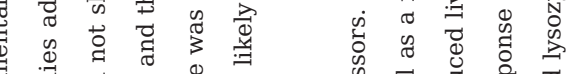

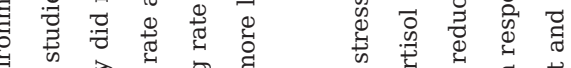

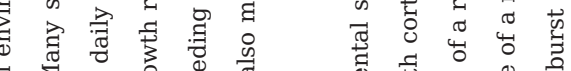

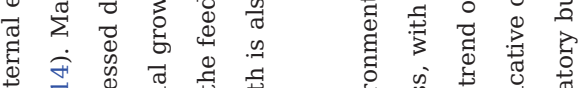

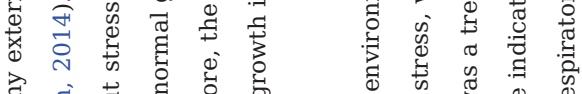

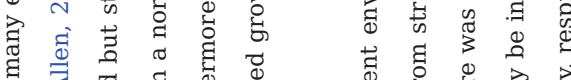

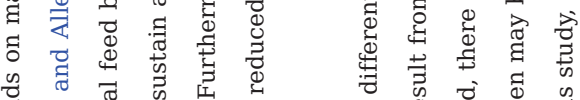

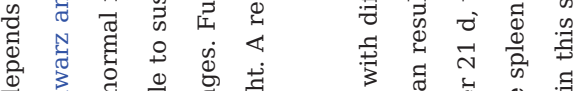

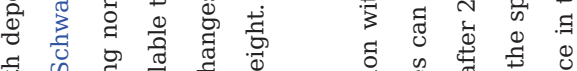

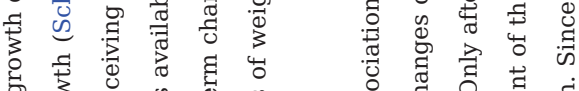

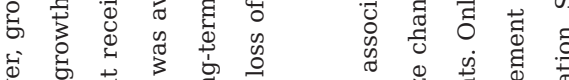

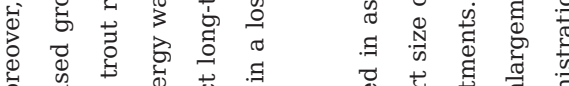

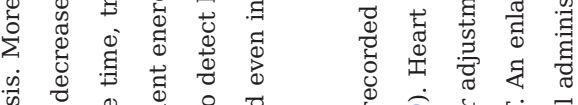

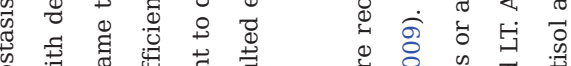

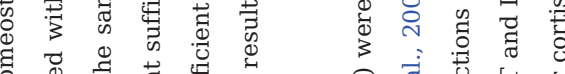

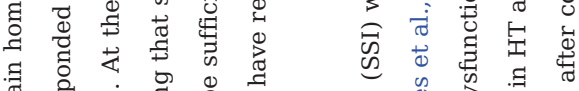

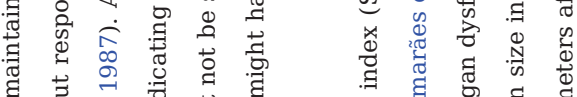

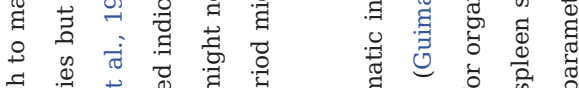

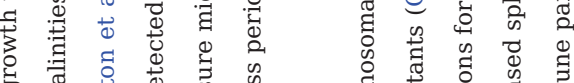

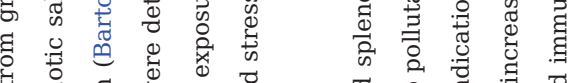

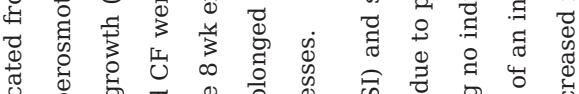

范

零 包

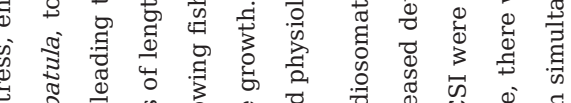

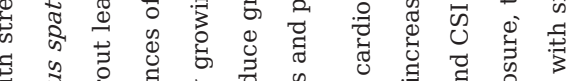

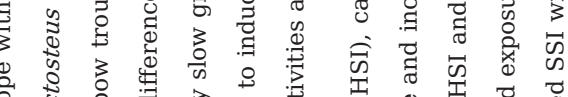

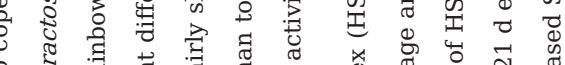

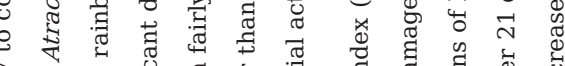
勇焉

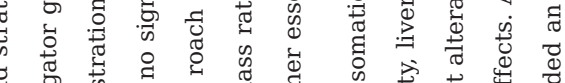

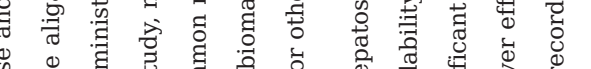

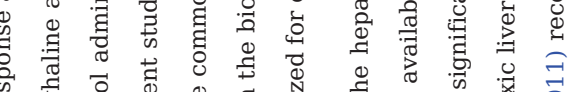

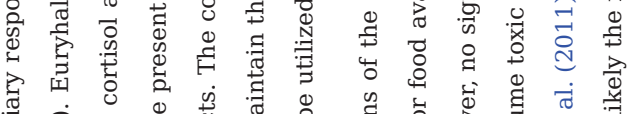

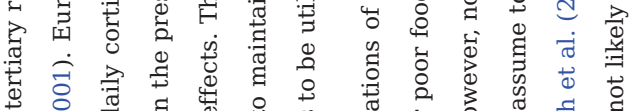
苛

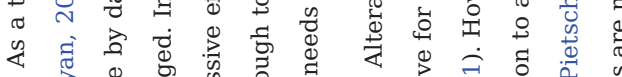

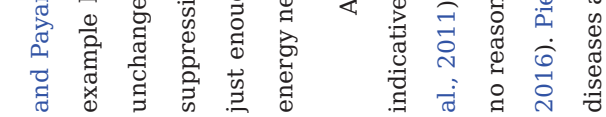




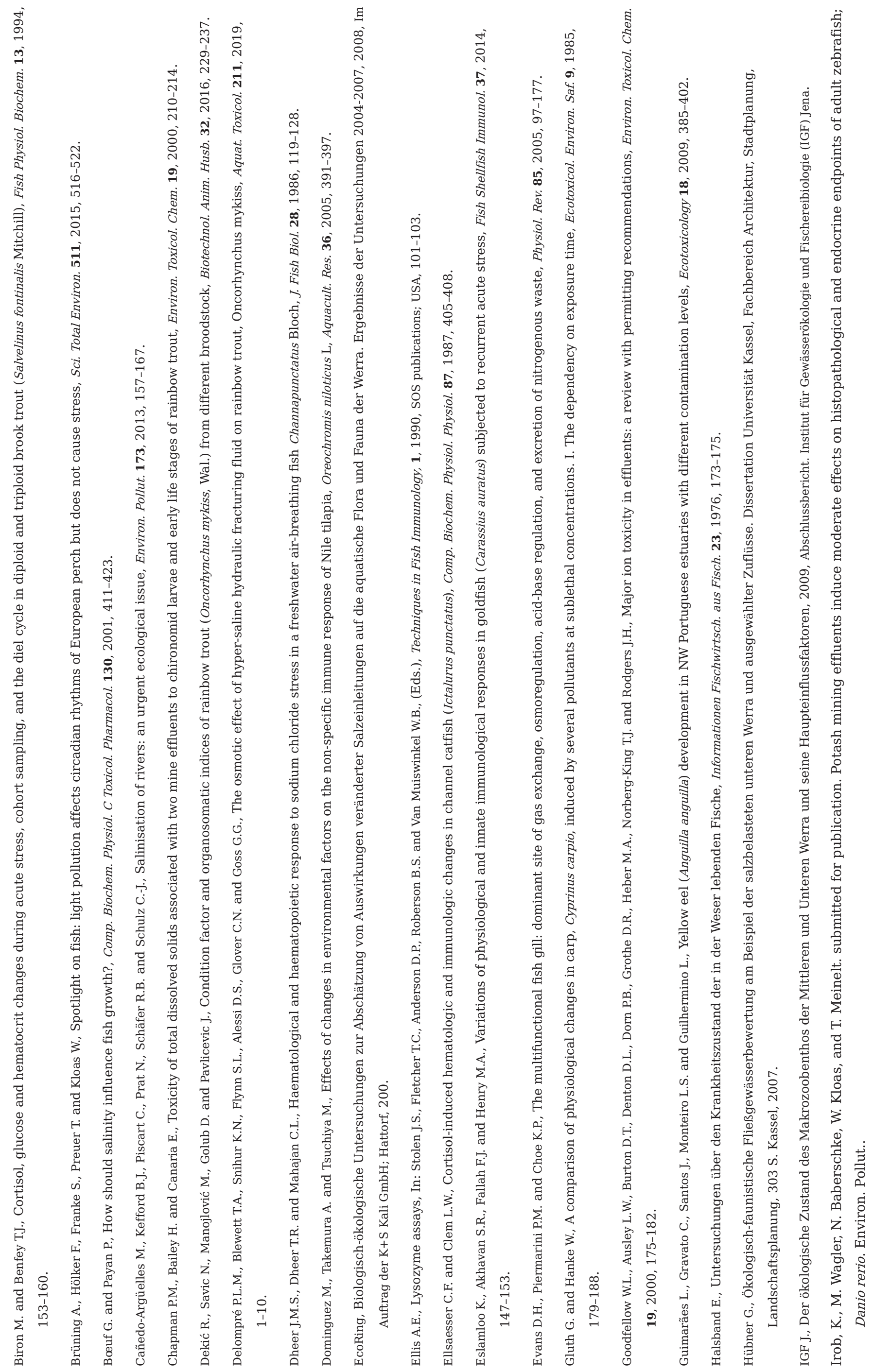




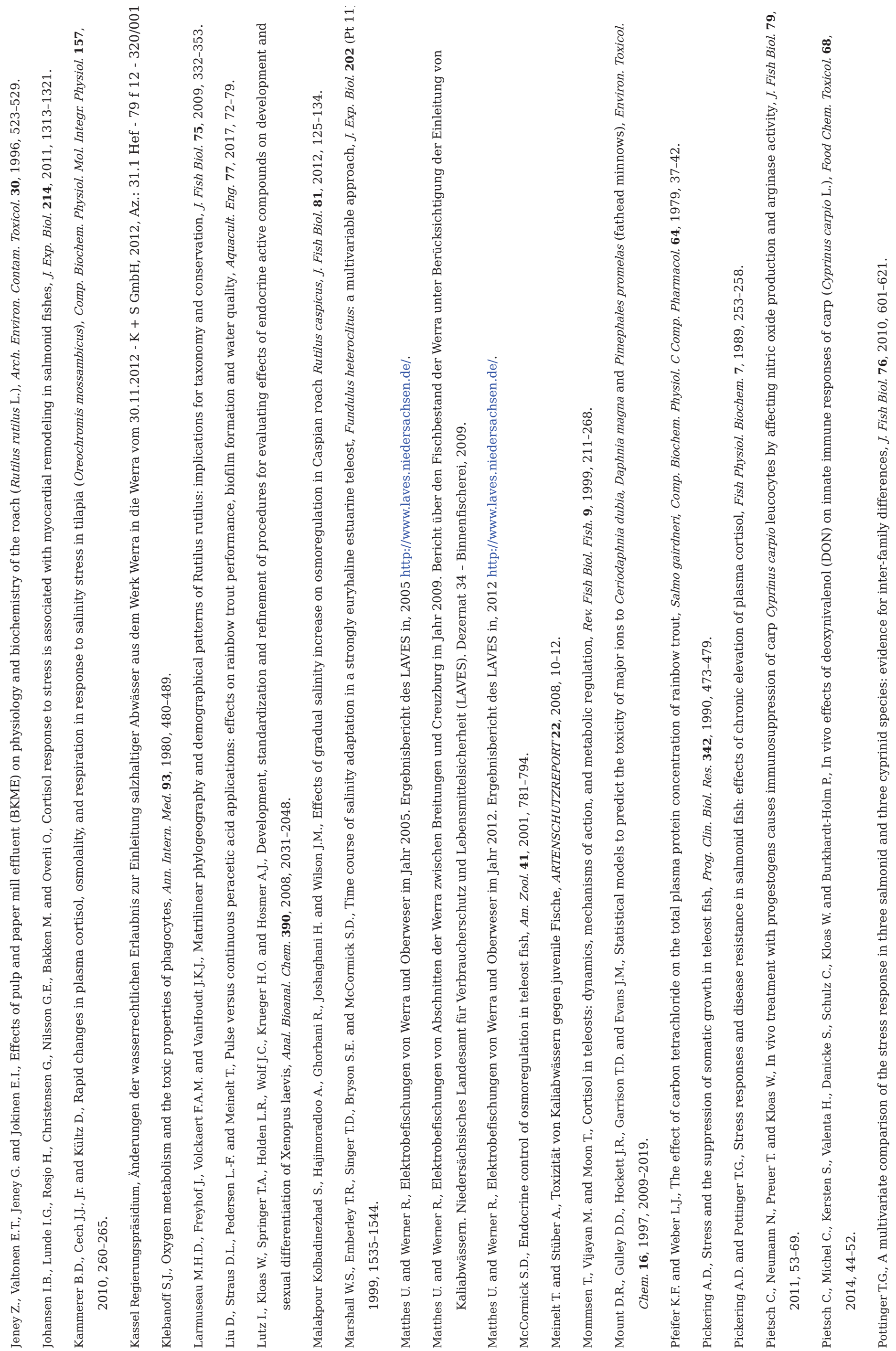




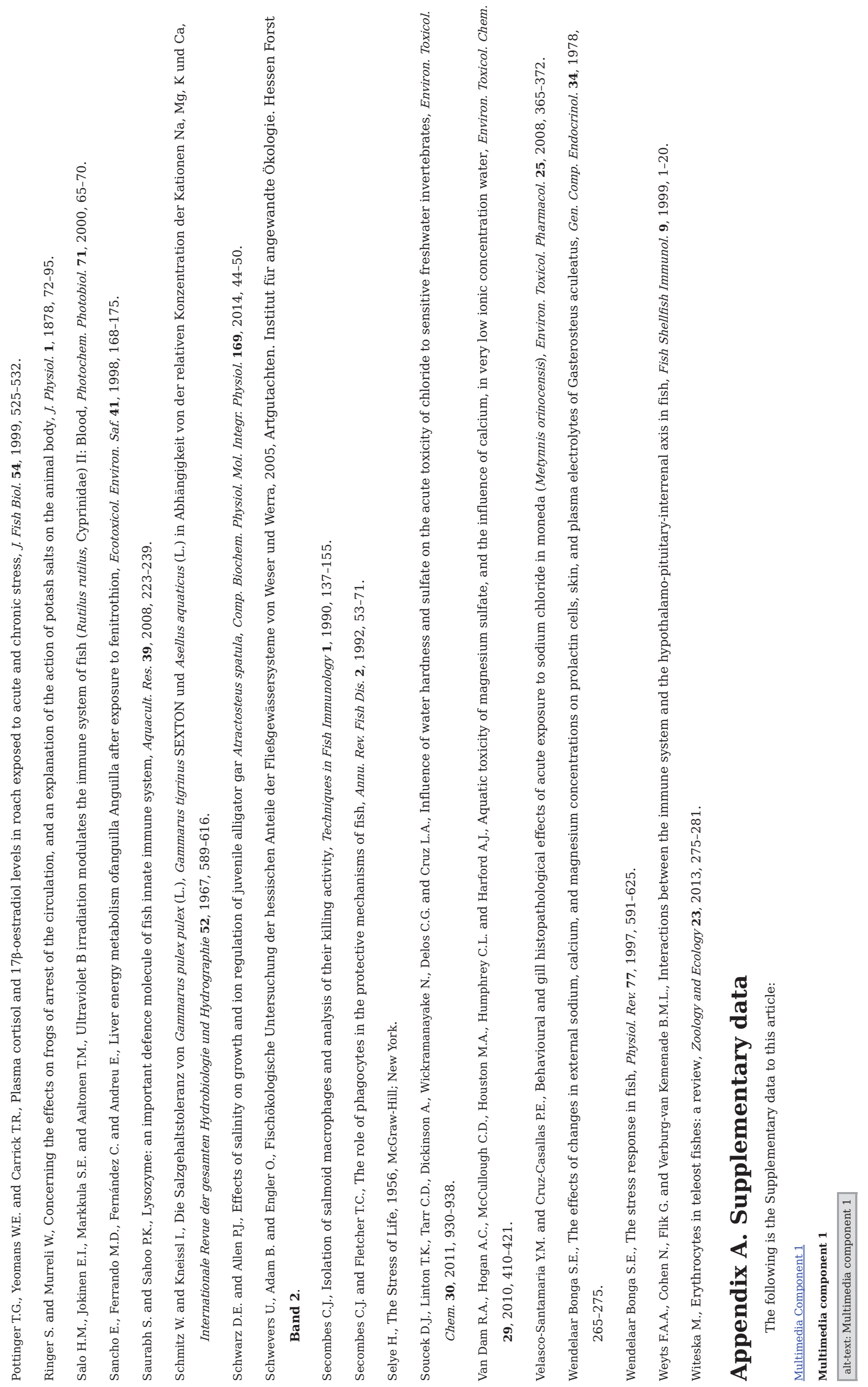

